\title{
Notions of Mandate, Knowledge and Research in Norwegian Classical Music Performance Studies
}

\author{
Elin Angelo ${ }^{1 \star}$; Øivind Varkøy ${ }^{2}$ and Eva Georgii-Hemming ${ }^{3}$ \\ ${ }^{1}$ Norwegian University of Science and Technology, NTNU; ${ }^{2}$ Norwegian Academy of Music \\ and ${ }^{3}$ Örebro University
}

\begin{abstract}
Policy changes and higher education reforms challenge performing musician programmes across Europe. The academisation of arts education means that classical performance programmes are now marked by strong expectations of research paths, publications, and the standardisation of courses, grades and positions. Drawing on interviews with ten teachers and leaders within the field of higher music education, this article discusses notions of mandate, knowledge and research in classical performance music education in Norway. Against the backdrop of academisation, the aim of this article is to illuminate central tensions and negotiations concerning mandate, knowledge and research within higher music education. The problem concerns issues of who should be judged as qualified and who should have the authority to speak on behalf of the performing music expertise community. The study is part of the larger study Discourses of Academisation and the Music Profession in Higher Music Education (DAPHME), conducted by a team of senior researchers in Sweden, Norway and Germany. Through an analytic-theoretical reading of the empirical data, informed by Foucault's power/knowledge concept, two discourses on mandate are identified (the awakening discourse and the Bildung discourse) as well as three discourses on knowledge (the handicraft discourse, the entrepreneurship discourse and the discourse of critical reflection) and two discourses on research (the collaborative discourse and the 'perforesearch' discourse). The latter of the two research discourses pinpoints a subject position as a musician/researcher with knowledge, craft and skills in both music performing and research.
\end{abstract}

Keyword: Higher music education; academisation; performing arts programmes and research; artistic research/developmental work; discourse theory; power/knowledge

Received: June, 2018; Accepted: April, 2019; Published: September, 2019

\section{Introduction}

Ever since the $17^{\text {th }}$ century and the foundation of conservatoires, the vocational training of orchestra musicians in most European countries has taken place at conservatoires,

^Correspondance: Elin Angelo, epost: elin.angelo@ntnu.no

(C) 2019 E. Angelo, Ø. Varkøy and E. Georgii-Hemming. This is an Open Access article distributed under the terms of the Creative Commons Attribution 4.0 International License (https://creativecommons.org/licenses/by-nc/4.0/), allowing third parties to copy and redistribute the material in any medium or format and to remix, transform, and build upon the material for any purpose, even commercially, provided the original work is properly cited and states its license. Citation: E. Angelo, Ø. Varkøy and E. Georgii-Hemming. «Notions of Mandate, Knowledge and Research in Norwegian Classical Music Performance Studies». Fournal for Research in Arts and Sports Education, Special Issue: «Community Arts/Arts 78 Education»Vol. 3(1), 2019, pp. 78-100. http://dx.doi.org/10.23865/jased.v3.1284 
independent academies and music colleges. Such institutions traditionally emphasise artistic practices, such as instrumental or vocational studies, typically in the continental European tradition, training the students for the performing music profession. According to Mills (2002) and Gaunt (2008), it is common to place a high value on individual development. Even if both a university and a conservatoire education can lead to a bachelor's degree, a conservatoire is more likely to focus on disciplines such as strings, piano or vocals than universities, which have a stronger focus on academic issues, such as analysis, harmony and the philosophy of performing arts.

The academisation of arts education means that higher music education in general is now marked by strong expectations of research paths, publications, the standardisation of courses, grades and positions. As vocational education becomes more university-like, traditional notions of knowledge and competence are challenged (cf. Kyvik, 2006). However, not just the processes of academisation are challenging current performing arts education. Also the labour market for today's musicians has changed radically. The profession is practiced within a diverse and complex landscape of shifting demands for knowledge and competence (Angelo, 2016).

In Norway, several music conservatoires, originally organised for the vocational training of musicians and music performance teachers, have merged with larger universities or university colleges during the last $5-10$ years. This consolidates vocational, artistic and academic education within university settings, and intrudes on the traditional norms and notions of mandate, knowledge and research in the institutions, such as emphasis on handicraft versus emphasis on reflection, or emphasis on performance versus emphasis on publication.

Our study investigates how the processes of academisation affect performing musician programmes, and in this article, we will explore contrasting perspectives on three central concepts. The article is guided by the research question, "What notions of mandate, knowledge and research are constructed among performance teachers and leaders in higher music education in Norway?" Notions of mandate, knowledge and research are both (a) main concerns in the DAPHME project as a whole, in all three countries involved related to the backdrop of academisation, and (b) central aspects in the interviewee's reflections on the data material for this article.

The article is divided into four sections. In our study, academisation is not the analytical concept per se. Rather, based on previous higher education research, it is the point of departure for our explorations. However, we firstly position the study in the field of research on 'academisation' in higher education. Secondly, we explain our research methodology and the chosen discourse-theoretical approach. Third, we discuss the identified discourses on mandate, knowledge and research and the profiles of higher music education in Norway that these might establish. And finally, to conclude, we discuss the possible consequences that the identified notions might have for further development in and of higher music education. 


\section{An 'Academisation' Outline}

The context for our study is the ongoing changes in higher music education as a result of diverse social and educational reforms (e.g., The European Higher Education Area, no date; European Communities, 2008, European Parliament, 2000, 2006; Ministry of Education, 2009; Ministry of Education, Ministry of Local Government and Regional Development \& Ministry of Trade and Industry, 2009). With regard to the relationship between practice and theory, researchers discuss this in terms of a general trend towards an 'academisation' of the college sector in most Western European countries (Kezar, 2004; Kyvik, 2006; Messel \& Smeby, 2017; Osland, 2017; Thue, 2017; Wolter \& Kerst, 2015). Academisation here indicates a process where theoretical and verbal aspects of the education are stressed at the expense of practical and bodily aspects, and as a process that changes the required teacher competence in more theoretical, analytical and academic directions. These changes have been met with both enthusiasm and scepticism.

Norway is an interesting case in point here. Kyvik says that the Norwegian college sector is one of the most academically oriented in Western Europe, especially regarding career structure and degrees (Kyvik, 2006). As of 2015, the academisation of the university sector in Norway accelerated as a result of a state-defined restructuring of higher education, thereby initiating a comprehensive merging of colleges and universities (Ministry of Education, 2014-2015; cf. Slottemo, 2016).

A consequence of policy changes and higher education reforms is that research is integrated at the levels of bachelor and master programmes and also in vocational and craft-oriented studies. From a teacher's perspective, one challenge that has emerged in relation to the developments may be that teachers are expected to supervise research projects, even if they lack research education. From the perspective of music departments and institutions, fundamental ideas and values about artistic competence, knowledge and research are contested (Ek, Ideland, Jönsson \& Malmberg, 2013; Dyndahl, Karlsen, Nielsen \& Skårberg, 2017; Dyndahl, 2015; Gies, 2019, in press; Moberg, 2019; Moberg \& Georgii-Hemming, 2019, in press; Stige, 2015; Söderman, 2013; Söderman \& Sernhede, 2015, Tønsberg, 2013). For example, Stige (2015) states how the current situation, in which universities and university colleges can be seen as goal-oriented competitive entities, threaten basic values in music therapy, such as interpersonal sensitivity. In addition, research notes that academisation has also led to more formal and hierarchical decision-making procedures, which in turn have created a variety of informal structures and meetings between people in the academy. Instead of clear-cut authority lines and transparency, studies point to an opaque system leading to issues of formal and informal power structures (Krücken, 2014).

In 2018, a new PhD degree was introduced in Norway, spurred by European policy-making, such as the Bologna Declaration (The European Higher Education Area, 1999) and the Lisbon Strategy (European Parliament, 2000). Following the 
Norwegian Ministry of Education, the degree is termed "PhD i kunstnerisk utviklingsarbeid". Translated literally, it means $\mathrm{PhD}$ in artistic developmental work (Norwegian Ministry of Education and Research, 2018). In other words, the term is not 'artistic research'. Despite this, 'artistic research' is the English name used by all four Norwegian institutions that up until January 2019 have established a doctoral programme in this discipline. What is meant by 'research' or 'developmental work', and not least - if these terms contain differences - is not elaborated on by the Ministry of Education and Research (2018). Instead, the government leaves it up to the individual accredited institution, and the specific $\mathrm{PhD}$-programmes to decide the content, quality norms and profiles. The authors of this article find the terms 'developmental work', and 'research' to point in different directions: whereas 'research' surely implies examination of something, done with rigour and methodological transparency, 'developmental work' implies artistic progression within or between art disciplines, but not always investigation of posed research questions. The lack of clarity in the national guidelines blurs the lines between research work and art work. This can be viewed positively, as it provides more freedom and choices, but also as a concern, as it might de-qualify both art and research. Today, we find examples of programmes that require degrees from specific disciplines/instruments for entering the $\mathrm{PhD}$-education, and programmes that do not have this entrance requirement. We find programmes with a lot of emphasis on reflection and others with most emphasis on artistic originality. Due to the relatively vague regulations given by the Ministry, quite different $\mathrm{PhD}$-programmes might develop, with various views and norms concerning supervision, practices, peer-evaluation and connection to research communities. Tense debates show how such differences are major concerns among researchers, artists and educators in higher music and arts education in Norway. ${ }^{1}$ The main content of these debates is whether a doctoral degree in artistic developmental work should/ should not be regarded as a $P h D$ (doctor of philosophy); who should decide the standards, content and norms of the education, and what qualifications are needed for the supervisors of these programmes - PhDs, and/or artistic excellence.

To conclude this section, regardless of whether one looks at the political, formal and legal, social or epistemological aspects and motives, academisation denotes a transformational process. This process means transforming a profession- and practice-related educational system into a discipline- and academic-oriented system, where teaching has clear links to research. In this process, when professional thinking and artistic practice meet the idea of research and academic paradigms, it is likely

\footnotetext{
${ }^{1 \star}$ https://www.universitetsavisa.no/ytring/2017/10/23/Ph.d.-i-kunstnerisk-utviklingsarbeid--en-philosophiae-doctor-uten-forskning-69866.ece

*https://www.universitetsavisa.no/ytring/2017/10/30/Hvorfor-denne-mistroen-til-kunsten-70108.ece *https://www.universitetsavisa.no/ytring/2017/10/27/Ja-en-kunstnerisk-doktorgrad-er-veien-å-gå-70102.ece

*https://khrono.no/ny-doktorgrad-yngre-forskere-forskning/krass-kritikk-av-den-nye-doktorgradeni-kunstfag/133031
} 
that contrasting perspectives on performing musicians' expertise and societal mandate will arise, adding to political ambitions and economic interests.

\section{Methodology}

The data for this article consists of ten transcribed interviews (in Norwegian) with music performance teachers and leaders from four higher music education programmes in Norway. As a background, we also include syllabi and official website presentations from these four institutions. The four institutions were chosen randomly from the total number of eight institutions in Norway that offer music performance education on at least a master's level in classical music. The leaders we spoke to have responsibilities to both students and teachers as well as to research and education, and are part of senior management teams at their respective institutions. The teachers are from the same four institutions: two teachers each from two of the institutions and one teacher from each of the remaining two. Among the six teachers in total that we interviewed were two flautists, one church musician, one trombonist, one cellist and one viola player. Each 45-minute interview was conducted individually in the participant's workplace and focused on four themes: what knowledge the teacher's students need to develop, what kind of research is being conducted by the faculty of the teacher's institution, what the teacher's understanding of 'the classical music profession' is, and how academisation is influencing the teacher's work. All the interviews were transcribed, and for the purposes of this article we will examine them through a Foucauldian lens, searching for the primary discourses surrounding notions of mandate, knowledge and research in the context of higher music education. We read each transcript several times, looking for what each interviewee had to say about mandate, knowledge and research: what became stated as mandate, knowledge and research; how it (for example, research) was explained; how institutions, traditions and roles were positioned in relation to one another, and how commonalities in the statements made by our interviewees seemed to constitute bounded discourses on mandate, knowledge and research. In the analysis, we do not differentiate between 'the teachers' and 'the leaders', but consider these as diverse voices in the same field. All the interviewees are, or have been, classical music performers, and there are no remarkable differences between the leaders' and the teachers' reflections. If we were to divide the interviewees, categories such as wind players/string players or freelancers/institutional musicians would be equally as valid as teachers/leaders. Instead of dividing the interviewees into such categories, we consider all the interviewees as crucial voices in the landscape of classical higher music education in Norway. We are therefore not preoccupied with who says what, but instead, our focus concerns what is said.

The analytical approach is a discourse theoretical reading, informed by Foucault's concept of power/knowledge (1998/1980, 1999, 2008/1969) and inspired by Jackson and Mazzei's approach to theory-driven, qualitative research (2012). Following 
this, the approach is less concerned with specific analytical steps and more concerned with a theory-driven reading of the data material. This approach follows a considerable trend of discourse theoretical studies within Nordic research in music education from 2000 and beyond (Angelo \& Emstad, 2017; Apeland, 2005; GeorgiiHemming \& Westwall, 2010; Holmberg, 2010; Krüger, 2000; Kuuse, 2018; Lindgren \& Ericsson, 2010; Nerland, 2003; Onsrud, 2013; Rolle, Angelo \& Georgii-Hemming, 2017; Schei, 2007; Varkøy, 2001). In our reading of the interview transcriptions, we aim to identify how notions of mandate, knowledge and research are constructed through statements that presuppose and reaffirm specific understandings of power/ knowledge. For example, we could reveal notions of musical proficiency as first and foremost inborn and not actually teachable or possible to interrogate, and notions of 'research' as something verbal or auditory, conducted by performers and/or musicologists. Through scrutinising the leaders' and teachers' statements on mandate, knowledge and research, we might identify how they position themselves and others within the field of music/education/research, as well as what subject positions are constructed and what terms are used to characterise specific actions or events. In this reading, we attempt to identify ways in which our interviewees' statements presuppose particular power dynamics between students and teachers, performers and musicologists, those who play different instruments and the fields of education and professional performance. We are interested in how the interviewees frame their stories and explanations, what language recurs across multiple interviews, what patterns might be identified, what is elevated to primacy and what (who) is diminished by the absence of detail.

Foucault's concept of power/knowledge posits that certain kinds of knowledge presuppose certain power relations, while certain power relations presuppose specific knowledge $(1998 / 1980,1999,2008 / 1969)$. Foucault states that power is a productive force that exists everywhere and determines what can be known, and how, at the same time as knowledge is enabled by and through the specific power relations. Power and knowledge (fr: savoir) are mutually related and interactive. An example is how knowledge of craft in music education presupposes the existence of a master and a student and a hierarchical relationship between these two that reassures both parties that their shared enterprise has meaning. This master-apprentice relationship is a traditional and common way of teaching and learning in Western classical music performance education. The master's expertise is acknowledged by a musical community, and the student trusts the master's knowledge and ability. Placing trust in an acknowledged master allows the student to be accepted in the field and to acquire some of the master's skill and knowledge. Foucault never gave specific instructions on how to perform a discourse-theoretical analysis based on his concept of power/knowledge, but a number of his own studies demonstrate how this concept can be used to challenge the practices of civic institutions such as prisons and hospitals (Foucault, 1995/1975, 2003/1963). In this article, Foucault's concept of power/knowledge is employed to identify and discuss effects 


\section{E. Angelo et al.}

and knowledge that power fabricates when circulating in the teachers' and leaders' reflections.

In reading the interviews, we have not only been concerned with what is said and how it is phrased, but also with the ways in which our interviewees' statements are actually made possible by the presupposition of particular power dynamics. When the interviewees refer to entrepreneurship and the labour market, as opposed to entrepreneurship and the autonomy of art, this is suggestive of bias in the conception of musical education. Certain modes of reasoning are made 'normal' by discourses surrounding and constituting notions of mandate, knowledge and research in higher music education. We are concerned with identifying and discussing how such particular ideas come to be accepted as true among our interviewees and how such acceptance translates into particular attitudes, disciplines and topics in higher music education, as well as in the allocation of institutional resources to areas like faculty positions, scholarships and research funding.

Our analytical work is positioned within a social constructivist paradigm, where we are first and foremost occupied with verbal language as the medium for knowledge production and meaning-making. This position enables us to consider certain types of knowledge and prohibits us to consider meanings and knowledge that are not verbally expressed. The interviewees' statements might reach deeper than our position allows us to follow, and, for example, also contain bodily and material layers beyond the words. While this is left out in this article, our language-oriented position provides possibilities to carefully examine and discuss the interviewees' spoken reflections on mandate, knowledge and research in classical programmes in higher music education in Norway.

\section{Discourses on mandate, knowledge and research}

In this section, we present and discuss the identified discourses on mandate, knowledge and research. 'Mandate', 'knowledge' and 'research' are the aspects that we have enquired about and the keywords that have focused our reading of the interviews. For example, we asked the following questions when reading the interview transcriptions: what is said about knowledge, how is it being stated, how do sets of statements about knowledge create objects and subjects, what power dynamics are embedded in the explanations, and what is being taken for granted? In posing these questions, we have examined how the notions of mandate, knowledge and research are constructed and constituted. Our findings also reveal how notions of mandate influence central discourses on knowledge and research. This is emphasised in the concluding part of the article.

\section{Mandate}

We identified the following two discourses surrounding the concept of societal mandate in our interview transcripts: (1) the awakening discourse and (2) the Bildung discourse. 
The awakening discourse builds on an understanding of art, musicianship and higher music education as fields that might reveal something new about humans and the world, whether it be a new form of expression, mode of knowledge or way of thinking. This discourse constructs both artists and art forms as subjects with agency, while it envisions society and the world as objects open to the possibility of change. It suggests that good artists and art are responsible for bringing about this change, and it relies on the acceptance of a mystical element as essential to good artistry. The discourse on awakening as a mandate for musicians and higher music education is based on what we found to be a view of musicians, shared by those interviewed for this study. The cello teacher illustrates this as "everything cannot be academised and spoken about. The process of creation, what happens in the head of an artist who forms an expression, cannot be explained. This is the spiritual part and the core of music performing education". This explanation places musicianship beyond the dominion of theoretical analysis and contributes to a notion of musicianship as something affective, intuitive or spiritual, and as this teacher put it, as something that exists beyond words. Musicianship is explained by the cello teacher as a kind of knowledge that develops when skills are internalised in a person and become intuitive to music performance, and at the same time as something inherent and personal that, with the right nurturing, might reveal new expressions, sounds and new ways of reasoning. The awakening discourse builds on such ideas and on a belief that human beings move through the world in a kind of anaesthetized state, waiting to be awakened by the mystical force of uncompromising artistic creation. In the following sections, we elaborate on how this discourse underlies various conceptions of knowledge and research.

The Bildung discourse also relates to an awakening of something or someone new (as in the awakening discourse discussed above), but is more focused on the cultivation of something that already exists. Concerning the concept of Bildung, it is focused on a continual process of personal development, in contrast to education as schooling. Tracing back to Hegel and a long German tradition of self-cultivation, processes of Bildung include individual spiritual and cultural sensibilities as well as social skills and unification, and they concern both a constant development of the human as well as of intellect and reflection. Humboldt's model of higher education positions this as part of a lifelong process of human development and not as mere training for certain external knowledge or skills. Starting in one's own cultural heritage, Bildung is about life-long 'journeys', meeting and dealing with the unknown (Varkøy, 2015). A central aspect in Bildung is competence in critical, nuanced and creative thinking and ethical reflection (Hagtvedt \& Ognjenovic, 2011). Creative and critical thinking are not regarded as new skills, in the tradition of Bildung, but as immanent capacities that can grow and be cultivated.

The Bildung discourse plays a significant role in the interviewees' statements about knowledge and research. Several of our interviewees speak about the role of music 


\section{E. Angelo et al.}

performance education in the betterment of humanity as a whole. The viola teacher states that a part of the task of higher music education is to make both students and teachers into 'ever better humans'. One of the flute teachers accentuates the duty of education to help students develop into creative and curious human beings with emotional competence as well as musical proficiency. "Charisma is teachable and learnable", she tells us, and she argues that a variety of art forms, including dance, poetry, drama and visual art, ought to be brought to bear in the education of musicians. She claims that this kind of interdisciplinary artistic education would serve to enhance both the artistic and the emotional capacity of both students and teachers. "We must contribute for the students to really live their lives! Live! Shout! Run! They find out if there is water in the pool when they land", she says, and warns that too much focus on technical practice kills the students' creativity. This statement constructs a polarity between a hard, disciplined life of endless practice and an easy, unproblematic life relieved of the necessity of practice and the drive of professional ambition. "Only very few get orchestra jobs. All the others are needed for other things", she states, arguing that for both those who would become professional musicians and all the other students, a dynamic artistic education could help to develop curiosity and contribute to a sense of happiness and wellbeing. This would not only be beneficial for the individual students and teachers, but also for society as a whole. In this formulation of musical education, human beings are conceived of as subjects capable of growth and development, and the flute teacher's formulation expresses the notion of mandate on display in the Bildung discourse.

This notion of mandate is further illustrated by what the trombone teacher states about the necessity of heritage knowledge. "Trombonists need to know where we come from, our cultural tree of musical heritage", he says, and explains this tree as a kind of 'family tree', encompassing composers, trombone performers and teachers, style elements and ways of playing. The trombone teacher sees the deepening of instrumental heritage knowledge as part of the mandate of higher music education and argues that encouraging the growth of historical consciousness is an essential element in this, stating: "Historical knowledge about 'our musical roots' is the foundation of us (classical trombonists) being here". Sets of statements among our interviewees view Bildung as a main mandate for higher music education. This also underpins statements regarding knowledge and research.

\section{Knowledge}

Three discourses emerged from the constructions of knowledge offered by our interviewees: (1) the discourse on handicraft, (2) the entrepreneurship discourse, and (3) the critical reflection discourse.

The discourse on handicraft was articulated by all of our participants. Technical craft seemed to be accepted as an obvious necessary form of knowledge for the classical 
musician and an essential component of musical education. This practical knowledge contained in the body and fingers seems to constitute an underlying basis in the field of classical music performance, and it works through systems in higher education, such as subjects, main teachers and important references. Education in classical music is organized around a primary instrument. Instruction in that primary instrument is conducted by a renowned musician who serves as a master to the student apprentice and teaches by means of one-on-one lessons and master classes in the student's chosen instrument and ensembles. The renowned musician-teacher travels between the educational institution and institutions in the professional music world, such as symphonic orchestras and military bands, and mediates significant notions on mandate and knowledge between these arenas. This constructs subjects (for example, primary instrument, secondary instrument ear training or ensemble), positions and roles (for example, instrumental teacher, theoretical teacher or performance student), artifacts and architecture in functional hierarchies relating to this primary instrument, and significant teacher in classical music education. Established power dynamics between, for example, teacher/student or instrumental teacher/theoretical teacher serve to encourage the development of forms of knowledge that then reinforce the established hierarchy. A leader at one institution refers to handicraft as the 'arch-traditional knowledge' in the field, and states that craftmanship displays a 'distinctive kind of quality' capable of massive and powerful reactions. He tells a story of when he heard a brilliant young violinist play in a symphony orchestra in New York. "In spite of being tired and jetlagged", he says, "I'm not sure if I suddenly woke up because I was crying, or if I was crying because I woke up, but that violinist ...!" He describes this as an experience that he will never forget and gives this as an example of how craft distinguishes great musicians. This description appeals to the notion of mandate that we found to be part of 'the awakening discourse': the notion that great musical performance comprises great power and stems from hard work and endless hours of dedicated practice. The church music teacher emphasises repertoire as a form of handicraft knowledge more than the other teachers in this study. This also relies on a hierarchical organization between 'the (important and necessary) repertoire' for being a church musician and 'the other repertoire'.

The handicraft discourse is well established among all the interviewees. Still, notions exist that handicraft knowledge can be both threatened and threatening in higher music education. Several of the interviewees express concern that increasing requirements to write, read and discuss might overshadow the time and dedication that students and teachers should have for practice. Others stress how this time is also threatened by an urge to educate all-round musicians, skilled in many areas other than playing music. The church musician explains this as a result of "a handicraft profession educated under a university's roof' and warns of the consequences it could have to "emphasise theory at the cost of valuable practice time". In casting theory and practice as opposed to one another, the teacher here offers a vision of musical and academic education as oppositional enterprises with substantially different mandates and practices. He expresses critique towards the extensive merging 


\section{E. Angelo et al.}

of higher music education into university settings, and points to how this challenges both positions, views on knowledge and traditions. For example, presuppositions on handicraft as 'arch-traditional knowledge', 'distinctive qualities' and skills that need careful development might be questioned in academic settings. "Church musicians have a large repertoire to learn, and time must be spent wisely in the education", the church music teacher explains. "Do not load this study with theory", he continues, "We need the church musicians to be competitive!" The church music teacher's primary concern lies with his students' prospects for employment, and he recognizes that in order to be professionally competitive, they must master the repertoire expected of church musicians in Norway. There are more and more applicants for such positions, from many parts of the world.

As researchers, we expected to hear even more concern about the place of theory in higher music education than we actually did. We found it surprising that most interviewees embrace and 'fuel' the understanding that competence in verbalization and articulation is needed for tomorrow's musicians. The viola teacher argues that "wording activity' is every bit as important to the teaching of music performance as 'audio activity". This teacher devotes a great deal of time to discussions of music, education and standards with both colleagues and students. He writes chapters and books independently and with colleagues/students and finds this to be a meaningful part of his work as a performing music teacher. He says that: "even though this is a practice-oriented tradition (to play), we also need words about what we do - for example, when it comes to the task of leading a chamber orchestra. This is not just something everyone can do, even though this seems to be an assumption in some places". He explains that several of his colleagues and students have also become increasingly occupied with 'word work'. They are not only concerned with playing, performing and practising, but also engage in writing and discussing. The acknowledgment of such work as a vital part of higher music education challenges the well-established hierarchies and relations of power/ knowledge that performing programmes are built upon, such as the tradition of the primary instrument/teacher as the given pivot point. An emphasis on the acquisition of other forms of knowledge besides craft challenges the traditional views, and therefore the main power/knowledge conditions, that classical higher music education relies on.

Conceptions of music education that might undermine the focus on craft were articulated by one of the flute teachers, who argued that higher music education ought to concern itself with 'humans as a whole'. "Long hours spent in small practice rooms is a repetitious practice, and should only be undertaken by those who stand a reasonable chance of establishing a professional career in performance", she says, and suggests that specialization, whether in performance, teaching or administration, should be chosen early in the student's course of study. This teacher argues in favour of the education of 'humans as a whole' and advocates the use of approaches and techniques borrowed from other artistic disciplines like dance and drama. She argues that: "the aim of music education ought to be to cultivate students" humility and dignity and to prepare the students to master their own lives both within 
and outside the conservatoire'. One of the leaders warns that a lack of handicraft knowledge might become a consequence of the 'artistic research' doctoral programmes, and asks: "for or from what subject do they produce, or require, excellent handicraft knowledge?" He continues: "Without the premise of handicraft knowledge, how should committees rank applicants for scholarships or professional positions or formulate announcements for new positions? What are professors and $\mathrm{PhD}$ candidates in artistic research 'good at'? What is their subject expertise?" According to this leader, 'artistic research' can both challenge and change the established norms for knowledge development in and for higher music education, which has concentrated on topics such as flute performance, music history, church music or music education. However, choosing the areas and ways of research that are appropriate for education in classical music is not necessarily a straightforward process.

The entrepreneurship discourse is articulated with two different directions. Both of them connect to entrepreneurial competence, which, since 2001, has become a key concept in international education policy development (European Parliament, 2000; Ministry of Education, Ministry of Local Government and Regional Development \& Ministry of Trade and Industry 2009; Støren, 2014). The term originates from Joseph Schumpeter's (1883-1950) thoughts on innovation and creative individuals as a means for a nation's economic drive and has today become a major concern for school leaders, teachers and educational organizations worldwide. The European Parliament has stated it as a key competence in lifelong learning (2006). The idea of entrepreneurship also contains non-commercial nuances connected to creative and ground-breaking thinking. Nevertheless, entrepreneurship, as understood in general, emphasises an economic, profit-making aspect. Critical views suggest that constant quality control and assessment lead to anxious normalization and, ultimately, a fear of one's own initiatives, which is the opposite of innovation and the much lauded 'entrepreneurial spirit'. It is also opposed to how artistic and aesthetic subjects are positioned as a means to nurture a culture of greedy consumers (Georgii-Hemming \& Lilliedahl, 2014).

The first direction of the discourse on entrepreneurship in this study includes the concept of the entrepreneur as a gründer, an innovative individual who generates revenue while attempting to benefit society in some way. Society is conceived of within this discourse as something to be both served and entertained, according to its varying demands. The role of the musician within this concept of society is a pragmatic and, perhaps, even a cynical one. The musician is viewed as an economic actor providing a desired service to meet market demands. Our interviewees expressed both enthusiasm and scepticism in response to this model of the role of the musician in society. The church music teacher stated that increasing expectations for church musicians to be cross-genre, to manage different things and include more popular music in church services force music students and instructors to prioritise the wrong things. He is not happy about this, but says: "it's the way things 


\section{E. Angelo et al.}

have become". Several of the teachers and leaders express concern that the growing demand for cross-genre musicians might marginalise the established classical canon. Others, however, assert that the place of the canon is secure. As one of the leaders puts it: "The classical canon is safely anchored in our culture and will therefore always be a requirement for classical, schooled musicians". Such statements serve to preserve the place of the canon and maintain power behind the move to stabilise the established knowledge culture and then perpetuate the hierarchical organisation of classical music. Statements made by our interviewees suggest that both the focus on craft and the supremacy of the classical canon, continue to hold pride of place in the realm of musical education.

The second path of the discourse on entrepreneurship constructs the artistic entrepreneur as an autonomous agent who possesses the power, skill and drive to change and improve society. This line of discourse envisions society as being in need of change and suggests it ought to be viewed with an eye towards opportunities for improvement. This entrepreneurship discourse corresponds to the awakening discourse discussed earlier, in that it includes a notion of society as being in need of awakening by individuals with vision. The cello teacher puts it like this: "The mandate of music is to provoke, make new thoughts and new insights and question taken-for-granted opinions in society about business, for example, and the meaning of enterprises and big firms". In this, the teacher casts the role of the musician as a rebellious one, suggesting that musicians possess a unique power to bring about social change. He further states that 'knowledge is perishable' and therefore cannot be kept in good shape for long. One needs knowledge that is up-to-date and fresh at all times. "Knowledge must always be open to change", he says, underlining an understanding of the world as being in motion and then also outlining a notion of knowledge as non-static.

The cello teacher tells us that: "musicians have always been obliged to make their own vocation; this is nothing new". He adds, though, that the notion of the musician as an entrepreneur is new, as is the growing place of the idea of entrepreneurship in music education. To him, this seems a risky development that places more emphasis on industry than art, which raises the question of what makes a real artist. The cello teacher seems to see a contrast between the genuine artist, possessing the talent and ability to awaken the society around him, and the industrial artist, who produces art only in response to the demands of the free market. He underscores that economic and artistic interests might be in deep conflict and that market demand can interfere and reduce the quality of artistic expression. "Classical music and classical musicians are needed as a counterweight to entertainment culture as well as publication scores", he stresses. The mandate of the classical musician, as this teacher sees it, is specifically to offer an understanding of the world that differs from the societal forces around him. This view is widely held in the realm of higher music education. All of our interviewees bring up an understanding of the musician as someone possessing a unique ability and indicate that this is something that students can only tap into when reaching advanced levels on their instruments. Even if this is a very 'foggy' 
notion of both mandate and knowledge, it seems like an established 'truth' that not even the most economic classical musician would dare to contradict, for fear of being completely excluded from the musical highbrows. The power of fogginess and mysticism also works as a shield to deflect and invalidate questions from those who do not have this expertise. This power/knowledge condition seems crucial in classical, higher music education and serves to reinforce the necessary hierarchies and authority for this knowledge to further develop.

Both elements of the entrepreneurship discourse suggest that mere technical ability is insufficient for the next generation of musicians. Music students also need to consider their place in society and in the labour market and decide whether their interest lies in appealing to societal forces or changing them. One of the flute teachers elaborates on a shifting labour market for musicians and admits, with humiliation, that: "there still exist positions for musicians where you don't have to use your head, where all is set up for you, and you don't need to worry about what to play, where you will play, with whom, and who will lead it". Here, she refers to the few students who might land permanent positions in symphony orchestras or military bands. In these institutions, every aspect of the musician's work is already established, and the musician must simply play well. Such positions are very rare, though, and as the flute teacher explains: "most students will need to both create and run their own business, and in order to do this, they will require a number of skills related to business operations, such as grant writing, networking and advertising". The flute teacher has created a number of new classes geared towards developing business acumen in her master's-level students. One of the most successful of these courses has been 'Experts in Team', in which instructors from diverse backgrounds and professional fields come in to lecture to students. The idea behind this course is that success in one field, conducted by one expert, plus success in another field, conducted by another expert, should lead to double success and great innovation. This idea also activates power and knowledge conditions from other areas, such as economics, geography or health, in higher music education. The traditions for knowledge development, judging of expertise and research quality might differ significantly between the cultures of these 'experts', and this subject might then contribute to destabilising the established hierarchies, aims and values in higher music education.

The critical reflection discourse concerns the ability to articulate and discuss the point of an argument. Critical reflection is part of both aspects of the entrepreneurship discourse, but in quite different ways. Good verbal skills are essential to business operations, as many of our interviewees point out. At the same time, the inspired artist is no less dependent on communication skills than the hardworking entrepreneur. However, much of the work done by the musician requires no verbal skills but merely musical ability.

The discourse on critical reflection is anchored in an understanding of higher music education as part of an educational system that seeks to develop responsible and active members of a democratic society. 'Democratic' here points to the demands 


\section{E. Angelo et al.}

for everyone to exercise power through discussions and voting, and to have a say in important matters. This understanding also coincides with the discourses discussed earlier on mandate, Bildung and awakening. One of the leaders states that "all professional education is a further education after upper secondary school and is therefore responsible for the further development of the students' abilities to speak, write and read. This is general knowledge that all adults in a democratic society need". He explains that all adult members of society need to be able to think critically and articulate their thoughts, and he elaborates this by saying: "musicians increasingly need this skill because reporting, documenting, communicating and reflecting is also part of their work". These statements contribute to a construction of musicians as democratic actors and responsible members of a society who are capable of identifying and discussing challenges. In some ways, this contradicts the notion of the autonomous artist presented above, but all the interviewees underline the need for some form of training in verbal communication as part of higher music education.

The viola teacher, who is also a renowned musician, argues that verbal communication is not only an important aspect of his job, but also an important element of being human. He views the 'wording' activity as an equally significant part of his work as a violist/viola teacher as the practical, playing part. Working with words through speaking and writing is not seen as a boring routine, but as a creative part of his job as a musician: "Reflection has become a bigger part of music education and is no longer a task only for the academics, the music history teachers and the music theory teachers, but also for the performing music teachers", he says. This statement contributes to a notion of the performing musician as one who also engages in research and writing. The interviewees express different attitudes towards this concept of the musician. To some extent, they all agree on the need to develop verbal communication skills, but we found little consensus on the opinion that the performer also ought to participate in research and speaking engagements. Still, several of the teachers and leaders in this study strongly emphasise that good musicians must also be able to speak, write and question what they do. One of the flute teachers underlines "an ethical reason for this", stating that: "There is so much 'hazy talk' in this field. Hazy talk often rises from hazy thoughts that are seldom considered and reflected upon". Still, the hazy talk often gets the consensus and has an influence on developments in music education, making decisions and norms that are unquestionable and immune to critique, she explains. In this, she delves into the 'fogginess' and 'mysticism' surrounding the thought of the extraordinarily good musician and adored music educator. Many of the teachers and leaders, like this flute teacher, stress the need for more openness with regard to the work done by musicians, and they emphasise that training in verbal communication is essential for such openness. This idea of openness, however, is built upon an expectation that musicians will conduct research and development in addition to mastering their instruments. Several interviewees express concern that this might overburden students and that an emphasis on research might come at the expense of musical proficiency. 
Research

Two main discourses on research were identified in the interviews. Both concern the place of performance music in research and the place of research in music performance education. The primary distinction between these two notions is the question of whether a performing musician should conduct his or her own original research or collaborate with academics to conduct or participate in research. We call the first of these two the 'perforesearch' discourse, where the word 'perforesearch' combines the words 'performance' and 'research'. The second we will refer to as the collaborative discourse.

These two ways of conceptualizing research in the field of higher music education are based on the traditional division in higher music education between 'the academic ones' (with education in music history, music theory, music psychology and music sociology), and 'the performing ones' and to some extent also 'the teaching ones' - even if that actually concerns all employees in higher music education institutions. In this division, academics are constructed as subjects that are occupied with, interested in, and qualified for research into the object of music, while performers are viewed as artists and creators. The trombone teacher admits: "I have never been fond of research. Researchers often seem a little "far out", if you know what I mean". This statement contributes to a division between musicians who deal with 'the real stuff' of music, and more peripheral researchers, casting the work of researchers as strange and of limited interest. This teacher stresses, however, that he is interested in research regarding the role of practicing, as this is, in his words: "a relevant and important field to develop for a musician". One of the leaders explains that he encourages collaboration between academic employees and performance employees in his department, but states that: "this is challenging and can, in the worst case, lead to amateurism and trivializing music performance as well as research. In the best cases, it can lead to fruitful and significant development". This statement fuels the notion of academics and performers as members of different, and not infrequently opposed, groups. One of the flute teachers says: "We (all the musicians/teachers) have $50 \%$ of our time for research and development in our positions. Of course, there could sometimes be reasons to examine what actually happens in these hours". This suspicion of research activity may seem out of place in an educational institution, but all of our interviewees expressed a similar sentiment. "It becomes awkwardly silent when I talk about research in this environment (performing music)", one of the leaders says, laughing, and continues: "People look at me questioningly, and I am only interrupted by over-stressed contributions and hostile outbreaks". Several of the interviewees talk about research as being possible through collaboration between academics and performers in higher music education. In this, both parties will have expertise and the confidence to contribute. However, the trombone teacher raises the essential question of whether such collaborative research has any real-world relevance or whether it is just something 'far out' that is only valuable for credit points in an institutional context. 


\section{E. Angelo et al.}

The artistic perforesearch discourse suggests that research ought to be conducted by performers and by students and teachers of music performance. This means that instrumental teachers and instrumental students should initiate, conduct and participate in research activities. The empirical data leaves open the question of what kind of research should be conducted, but the reasoning of this discourse casts musicians as those who are best prepared for relevant and important research in music and emphasises that music performance research "should be about music performance", as one leader emphatically states. We find no clear notions among those interviewed as to where the line should be drawn between the (ordinary) activities of practice/performance and the activities of research. All the teachers interviewed for this study list research and development as part of their positions, and our questions concerning the kinds of research teachers were currently involved with or wished to take part in were met with varying levels of enthusiasm, irritation or embarrassment.

One of the flute teachers states: "It would be the perfect combination, wouldn't it? A top-level musician who is also a top-level teacher and a top-level researcher!" She states that music education should support the broad development of knowledge and skills, and she indicates that individuals with just that kind of competence are strongly needed in political contexts. Both musicians and music education are dependent upon those who are willing and able to speak in clear and authoritative language about the place and value of music in society. She continues: "It is sad, the one musician together with nine attorneys in a board meeting about funding for the local orchestra or in the academic council at the university. One needs to train the abilities for arguing and reasoning in education. Music students cannot only practice their instruments for nine full years!" Another view is expressed by a leader who worries that what we here call 'the perforesearch discourse' might lead to a glorification of amateurism that would end up producing both 'bad art and bad research'. He explains how both research and artistic performance are built upon craft and specialization, but underlines that these kinds of expertise are very different. He also worries that the demands for research in performing music education can lead to an educational system in which neither the students nor teachers are encouraged to become experts in a particular specialty. He elaborates by stating: "Some institutions offer a $\mathrm{PhD}$, where half of it is performing and the other half is academic writing. These programmes are based upon completion of a bachelor's or master's programme, where the students haven't necessarily written anything. I wonder what kind of competence these PhD students actually have when they are finished". In this, he reflects a perforesearch discourse within higher music education, which he is sceptical about. He argues that instead of mixing two good things into one bad thing, one should rather go beyond this issue of research and performance and ask what 'critical reflection' should be viewed as. This must not necessarily be understood as an activity that requires words, but could also be seen as an activity that does not need verbal explanation. "Those with artistic knowledge should contribute to the definition of what critical reflection is", he states, and he then both constitutes and challenges the 'perforesearch discourse' on 
research. He takes part in this discourse by asserting that musicians have the requisite knowledge and experience to define and contribute to critical reflection in their field and in society, but he also challenges the discourse by expressing the concern of demanding both reflection/research and great musicianship from one person, as this could yield research and music that are equally bad.

\section{Conclusion}

In this article, we have identified and discussed central discourses surrounding mandate, knowledge and research in the interviewees' reflections on classical programmes in higher music education. Through a discourse-theoretical reading, guided by Foucault's concept of power/knoweldge (Foucault, 1998/1980, 1999, 2008/1969) we have scrutinized how the leaders and teachers position themselves and others within the field of music/education/research, what terms they use to characterise specific actions and events, how stories and explanations are framed, what/who is given precedence or diminished, and what they construct as strengths and weaknesses in higher music education programmes today. In this, we have identified tensions and negotiations, and contrasting perspectives concerning what mandate, knowledge and research higher music education manages. We now turn this focus towards the institutions and discuss how this relates to, challenges and potentially impacts power hierarchies, structures and attitudes within and around the classical programmes. With academisation as a backdrop, we are especially occupied with how increasing expectations of research, publications and standardisations influence the rhetoric, and how the identified discourses might affect the programmes on personal, disciplinary and institutional levels.

We have identified the notions on mandate as revolving around awakening new insights and cultivating good human beings and societies. First both the notions on knowledge and on research stem from these basic understandings. The notions on knowledge encompass handicraft and craftsmanship and substantiate refined, internalised skills as inevitable for achieving the mandate of awakening and Bildung. Second, the entrepreneurship discourse is also identified as a crucial part of the interviewees' notion of knowledge in classical music education. This is not only related to the economic conditions and to improving income and employment, but also to the expressed mandatory task of challenging the existing norms and systems and bringing forth new ideas. Third, the notions on knowledge also concern critical reflection and articulation, and it is this discourse in particular that seems to be highlighted and enlarged by the processes of academisation. Several of the interviewees express anxiety that the 'performing' aspect in performing music education is blocked by verbal, theoretical work. These concerns reoccur in the questions of research, where we have identified notions that question both qualification and authority. Who has the right qualifications to conduct research and knowledge development within classical, music education: the musicians or the (unmusical) researchers? We identified 


\section{E. Angelo et al.}

one discourse that highlights the 'academics' as best suited and another that suggests music performers are the only ones who can actually know and are therefore the only ones who can do 'actual' research.

The implication of academisation forces expert musicians to talk, read and write. It challenges the established hierarchies at institutions where the performing professors traditionally have been immune at the top, with internalised skills and indisputable expertise that no one would dare to question or challenge. These professors also meet the requirements of publishing and supervising $\mathrm{MA}$ and $\mathrm{PhD}$ work, which by definition are research-based activities. As such, the emphasis on reflection and research, identified in the interviewees' reflections, challenges structures and hierarchies on individual levels. These structures are, however, a decisive power/knowledge arrangement to help maintain the status, position, and interest in classical music education. Or, is this not the case? Could we be facing a turn towards educational programmes in classical music that are not master/apprentice-based and where speaking/writing is seen as a crucial part of classical musicians' specialised knowledge and skill? This, in turn, also challenge structures and hierarchies on the programme and institutional levels: for example, what will the difference be between academic, higher music education and performing music education? Why maintain all the different disciplines in handicraft rather than merge them into one? The music conservatoires are founded on the notion of handicraft and refined skills as the basis of art (with a capital A). The premise of academisation challenges this, by forcing the institutions to adapt to university grades, assessments, study plans and demands for publications and research.

Overall, attitudes, hierarchies, positions, disciplines and profiles in performing programmes seem to be challenged by academisation processes. This could be met by maintaining silence, or also by the will and interest to communicate and actively participate in dialogues. 'Publish or perish' is a bad ideal for higher music education, unless one redefines what is meant by 'publish'. Unless classical performers engage in (verbal) discussions about who their peers should be and what norms classical music educators should follow, and why, then these judgments will be left to non-musicians. A final conclusion in this article is, therefore, speak! Who is better qualified to say something about mandate, knowledge and research in and for higher music education than higher music educators themselves (teachers/leaders/researchers/students)? Only by verbalising the challenges, inviting dialogue and questioning of the qualifications (or the lack thereof), might one facilitate the academisation processes to work for and not against higher music education.

\section{Author biographies}

Elin Angelo (PhD) is Professor in Music Education at the Norwegian University of Science and Technology (NTNU), where she teaches undergraduate and graduate courses on music and arts education, research courses in the philosophy of science and methodology, and supervises BA, MA and PhD students. She is one of the founders and the elected chair of the Nordic Network for 'Kulturskole'-related Research, leader of the research 
network Music Teacher Education in Development, part of the research project DAPHME, and the research groups Music/Technology/Education (MusTed) and Art Education in Cooperation (KiS). She holds degrees from the Norwegian Academy of Music, the Arctic University of Norway and the Norwegian University of Science and Technology.

Øivind Varkøy (Dr.art.) is Professor in Music Education and Head of $\mathrm{PhD}$ education at the Norwegian Academy of Music, and Visiting Professor in Music at Oslo Metropolitan University. He has previously been Professor in Musicology at Örebro University (Sweden), and Associate Professor in Music at Innland University (Norway). Varkøy holds master degrees both in musicology (Oslo University) and music education (Norwegian Academy of Music), and a doctoral degree in musicology (Oslo University). He teaches bachelor, master and $\mathrm{PhD}$ courses in the philosophy of music education and philosophy of music, as well as theory of science, and supervises master and PhD students. He has published (and edited) a number of books and articles in the field of philosophy of music education in Norwegian, Swedish, German and English. Varkøy is part of the research project DAPHME.

Eva Georgii-Hemming $(\mathrm{PhD})$ is Professor in Musicology and Head of the School of Music, Theatre and Art, Örebro University, Sweden. She is principal investigator of the research project Discourses of Academization and the Music Profession in Higher Music Education (DAPHME), funded by Riksbankens Jubileumsfond (2016-2019), the main editor to the anthology Professional Knowledge in Music Teacher Education (2013), and has contributed to international anthologies such as Learning, Teaching and Musical Identity: Voices across Cultures and Future Prospects for Music Education: Corroborating Informal Learning Pedagogy as well as in international research journals, such as British fournal of Music Education, Research Studies in Music Education, Music Education Research, and Nordic Research in Music Education. Her research interests have also led to frequent presentations and keynotes at international conferences in Europe and the USA.

\section{Acknowledgements}

First of all, we would like to thank all the interviewees who welcomed us in to their institutions, and also read the final version of this article before publishing. We would also like to thank our colleagues in the research group DAPHME for good discussions concerning this article and Riksbankens Jubileumsfond for funding the DAPHME project. Our warm thanks also extend to the editors of JASEd and the two anonymous reviewers for their encouraging comments on an earlier draft of the article.

\section{References}

Angelo, E. (2016). Music Educators' Expertise and Mandate: Who Decides, Based on What? Action, Critisism and Theory in Music Education 15(2), 178-203.

Angelo, E., \& Emstad, A. B. (2017). Skolekonsepter som blir til i samarbeid mellom grunnskole og kulturskole ['School concepts' constructed in collaboration between compulsory school and music \& art schools]. In E. Angelo, A. Rønningen \& R.J. Rønning. Forskning og utvikling i kulturskolefeltet. Den doble regnbuen: IRISforsk. [Research and development in the field of 'kulturskole'. The double rainbow: IRISresearch] (pp. 207229). Oslo: Cappelen Akademisk. DOI: https://doi.org/10.23865/noasp. 21

Apeland, S. (2005). Kyrkjemusikkdiskursen. Musikklivet $i$ den norske kyrkja som diskursiv praksis. [The Church music discourse. Music life in the church of Norway as discoursive practice]. (Doctoral dissertation). Bergen: University of Bergen.

Dyndahl, P., Karlsen, S., Nielsen, S. G., \& Skårberg, O. (2017). The academisation of popular music in higher music education: the case of Norway. Music Education Research, 19(4), 438-454. DOI: 10.1080/ 14613808.2016 .1204280

Dyndahl, P. (2015). Academisation as Activism? Some Paradoxes. Finnish fournal of Music Education, 18(2), 20-32. 


\section{E. Angelo et al.}

European Communities. (2008). The European Qualifications Framework for Lifelong Learning. Luxembourg: Office for Official Publications of the European Communities. Retrieved from: https://ec.europa.eu/ ploteus/sites/eac-eqf/files/leaflet_en.pdf

European Parliament. (2006). Recommendation of the European Parliament and the Council of 18 December 2006 on Key Competences for Lifelong Learning. Retrieved from: https://eur-lex.europa.eu/legal-content/EN/ $\mathrm{TXT} /$ ?uri=celex$\% 3 \mathrm{~A} 32006 \mathrm{H} 0962$

European Parliament (2000). European Parliament. Lisbon European Council 23 and 24 March 2000. Presidency Conclusion. Retrieved from: http://www.europarl.europa.eu/summits/lis1_en.htm

Ek, A. C., Ideland, M., Jönsson, S., \& Malmberg, C. (2013). The Tension Between Marketisation and Academisation in Higher Education. Studies in Higher Education, 38(9), 1305-1318. doi: 10.1080/03075079.2011. 619656

Foucault, M. (2008/1969). The Archaeology of Knowledge. London and New York: Routledge.

Foucault, M. (1998/1980). Power/Knowledge: Selected Interviews and Other Writings: 1972-1977. New York: Pantheon Books.

Foucault, M. (1999). Diskursens orden: tiltredelsesforelesning holdt ved College de France 2. desember 1970. [Order of discourse: accession lecture held at the Collège de France on December 2, 1970]. Oslo: Spartacus.

Foucault, M. (1995/1975). Discipline and Punish. The Birth of the Prison. New York: Second Vintage Books Edition.

Foucault, M. (2003/1963). The Birth of the Clinic: An Archaeology of Medical Perception. New York: Vintage Books Edition.

Gaunt, H. (2008). One-to-one Tuition in a Conservatoire: the Perceptions of Instrumental and Vocal Teachers. Psychology of Music, 36(2), 215-245.

Georgii-Hemming, E., \& Lilliedahl, J. (2014). Why "What" Matters: On the Content Dimension of Music Didactics. Philosophy of Music Education Review, 22(2), 132-155.

Georgii-Hemming, E., \& Westvall, M. (2010). Music Education - A Personal Matter? Examining the Current Discourses of Music Education in Sweden. British fournal of Music Education, 27(1), 21-33.

Gies, S. (2019, in press). How Music Performance Education Became Academic. On the History of Higher Music Education in Europe. In S. Gies \& J. H. Sætre (Eds). Becoming Musicians - Student Involvement and Teacher Collaboration in Higher Music Education. Oslo: The Norwegian Academy of Music.

Hagtvedt, B., \& Ognjenovic, G. (2011). Dannelse. Tenkning, modning, refleksjon. Nordiske perspektiver på allmenndannelsens nødvendighet $i$ høyere utdanning og forskning [Bildung. Thinking, maturation, reflection. Nordic perspectives on the necessity of general education (Bildung) in higher education and research]. Oslo: Dreyers Forlag.

Holmberg, K. (2010). Musik- och kulturskolan i senmoderniteten: reservat eller marknad? [The community school of music and art in late modernity: Reservation or market?] (Doctoral dissertation). Malmö: Malmö Academy of Music.

Jackson, A.Y., \& Mazzei, L.A. (2012). Thinking with Theory in Qualitative Research.Viewing Data Across Multiple Perspectives. London and New York: Routledge.

Kezar, A. (2004). Obtaining Integrity? Reviewing and Examining the Charter Between Higher Education and Society. The Review of Higher Education, 27(4), 429-459.

Krüger, T. (2000). Teacher Practice, Pedagogical Discourses and the Construction of Knowledge: Two Case Studies of Teachers at Work. (Doctoral dissertation). Bergen: Bergen University College.

Krücken, G. (2014). Higher Education Reforms and Unintended Consequences: a Research Agenda. Studies in Higher Education, 39(8), 1439-1450.

Kuuse, A.K (2018) "Liksom ett annat uppdrag": iscensättning av social rättvisa $i$ musikundervisningens retorik och praktik. ["Sort of another task": rhetorical and practical performances of social justice in music education] (Doctoral dissertation). Umeå: Umeå University

Kyvik, S. (2006). Endringsprocesser i høyskolesektoren iVest-Europa. Arbeidsnotat. [Change processes in the college sector in Western Europe. Work note.] NIFU STEP Oslo:. Retrieved from: https://brage.bibsys.no/xmlui/ bitstream/handle/11250/2353321/NIFUSTEPArbeidsnotat2006-7.pdf?sequence=1\&isAllowed=y.

Lindgren, M., \& Ericsson, C. (2010). The Rock Band Context as Discursive Governance in Music Education in Swedish Schools. Action, Criticism and Theory for Music Education, 9(3), 35-54.

Messel, J. \& Smeby, J.-C. (2017). Akademisering av høyskoleutdanningene. [Academizaton of college education] In S. Mausethagen \& J.-C. Smeby (red.), Kvalifisering til profesjonell yrkesutøvelse [Qualification for professional occupational practice] (pp. 44-56). Oslo: Universitetsforlaget.

Mills, J. (2002). Conservatoire Students' Perceptions of the Characteristics of Effective Instrumental and Vocal Tuition. Bulletin of the Council for Research in Music Education. Spring \& Summer, 153(4), 78-82. 


\section{Notions of Mandate, Knowledge and Research in Norwegian Classical Music}

Ministry of Education and Research (2018). Ny doktorgrad i kunstnerisk utviklingsarbeid. [New doctoral degree in artistic developmental work] Retrieved from: https:/www.regjeringen.no/no/aktuelt/ny-doktorgrad-ph.d.-i-kunstnerisk-utviklingsarbeid/id2583604/

Ministry of Education, (2014-2015). Konsentrasjon for kvalitet - Strukturreform i universitets- og høyskolesektoren. [Concentration for quality - Structural reform in the university and college sector] (Meld. St. 18. 2014 - 2015) Retrieved from: https:/www.regjeringen.no/no/dokumenter/meld.-st.-18-2014-2015/id2402377/

Ministry of Education (2009). Nasjonalt kvalifikasjonsrammeverk. [National Qualifications Framework]. Retrieved from: https:/www.regjeringen.no/no/tema/utdanning/voksnes_laering_og_kompetanse/artikler/ nasjonalt-kvalifikasjonsrammeverk/id601327/

Ministry of Education, Ministry of Local Government and Regional Development \& Ministry of Trade and Industry (2009). Entreprenørskap $i$ utdanningen - fra grunnskole til høyere utdanning 2009-2014. [Entrepreneurship in education - from primary school to higher education 2009-2014] Retrieved from: https://www.regjeringen.no/no/dokumenter/handlingsplan-entreprenorskap-i-utdannin/id575026/

Moberg, N. (2019). Academic Musicians - how Music Performance Students in Sweden Re-/negotiate Notions of Knowledge and Competence. In F. Pio, A. Kallio, Ø. Varkøy \& O. Zandén (Eds). Nordic Research in Music Education. Yearbook, Vol. 19 (pp. 53-74). Oslo: Norwegian Academy of Music.

Moberg, N., \& Georgii-Hemming, E. (2019, in press). Musicianship - Discursive Constructions of Autonomy and Independence Within Music Performance Programmes. In S. Gies and J. H. Sætre (Eds). Becoming Musicians -Student Involvement and Teacher Collaboration in Higher Music Education. Oslo: The Norwegian Academy of Music.

Nerland, M. (2003). Instrumentalundervisning som kulturell praksis: en diskursorientert studie av hovedinstrumentundervisningi høyere musikkutdanning. [Instrumental music education as cultural practice A discourseoriented study of main instrument teaching in higher music education]. (Doctoral dissertation). Oslo: Norwegian Academy of Music/ Unipub forlag.

Onsrud, S. V. (2013). Kjønn på spill - kjønn i spill. En studie av ungdomsskoleelevers musisering [Gender at stake - a study of secondary school students' 'musicking'] (Doctoral dissertation). Bergen: University of Bergen

Osland, O. (2017). Om «akademisering» av dei korte profesjonsutdanningane. [About "Academisation" of the short professional education]. Nytt Norsk Tidsskrift, 428-436. DOI: 10.18261/issn.1504-3053-2017-04-09

Rolle, C., Angelo, E., \& Georgii-Hemming, E. (2017). Mapping the methodological field of 'Discourse Analysis' in music education research. A review study Part 1. In A. Cvetko \& C. Rolle. (Eds.). Musikpädagogische Forschung/Research in Music Education, Vol. 38 ( pp. 153-164). Münster, New York: Waxmann.

Schei, T. B. (2007). Vokal identitet: en diskursteoretisk analyse av profesjonelle sangeres identitetsdannelse [Vocal identity: a discourse theoretical analysis of professional singers identity formation.]. (Doctoral dissertation). Bergen: University of Bergen.

Slottemo, H. G. (2016). Et HiNT av kunnskap - Ei historie om Høgskolen i Nord-Trøndelag, 1994-2016. [A HiNT of knowledge - A story about Nord-Trøndelag University College] Nytt Norsk Tidsskrift, 3, 34-44. DOI: 10.18261 issn. 1504-3053-2016-01-02-04

Stige, B. (2015). Music therapy as academic education: A five-year integrated MA Programme as a lighthouse model? In H.M Ridder \& G. Tsiris (Eds.) Special Issue; Music therapy in europe: Paths of professional development. Approaches: An interdisciplinary fournal of Music Therapy, 7(1), 54-61.

Söderman, J. (2013). The formation of 'Hip-Hop Academicus' - how American scholars talk about the academisation of Hip-hop. British fournal of Music Education, 30(3), 369-381. DOI: 10.1017/ S0265051713000089

Söderman, J., \& Sernhede, O. (2015). Hip-hop - What's in it for the academy? Self-understanding, pedagogy and aesthetical learning processes in everyday cultural praxis. Music Education Research, 18(2), 142155. DOI: $10.1080 / 14613808.2015 .1049257$

Støren, L. A. (2014). Entrepreneurship in higher education: Impacts on graduates' entrepreneurial intentions, activity and learning outcome. Education and Training, 56(8/9), 795-813, https://doi.org/10.1108/ET-062014-0070

The European Higher Education Area. (1999). Ministerial Conference Bologna 1999. Retrieved from: http://www. ehea.info/cid100210/ministerial-conference-bologna-1999.html

The European Higher Education Area (no date). Bologna process - European higher education area. Retrieved from www.ehea.info

Thue, F. W. (2017). Høgskoler på randen av universitetsstatus - akademisk løft eller dyp-politisering? [College Universities on the verge of university status - academic boost or deep politicization?] Nytt Norsk Tidsskrift, 34(3), 286-300. DOI: https://dx.doi.org/10.18261/issn.1504-3053-2017-03-06. 


\section{E. Angelo et al.}

Tønsberg, K. (2013). Akademiseringen av jazz, pop og rock - en dannelsesreise [The Academisation of Fazz, Pop and Rock - An Educational fourney]. Trondheim: Akademika.

Varkøy, Ø. (2015). Bildung. Between cultural heritage and the unknown, instrumentalism and existence. In M. Fleming, L. Bresler, \& J. O'Toole (Eds.), The routledge international handbook of the arts and education (pp. 19-29). London: Routledge.

Varkøy, Ø. (2001). Musikk for alt (og alle) - om musikksyn i norsk grunnskole. [Music for all (and everyone) - about the views on music in the Norwegian primary School] (Doctoral dissertation). Oslo: Universitetet i Oslo, det humanistiske fakultet.

Wolter, A., \& Kerst, C. (2015). The 'academization' of the German qualification system: Recent developments in the relationships between vocational training and higher education in Germany. Research in Comparative E International Education, 10(4), 510-524. 